\title{
CRISIS OF IDENTITY IN THE CONTEXT OF MACRO-SOCIAL CHANGES
}

\section{Hermína Mareková ${ }^{1}$}

\begin{abstract}
Identity formation involves all of us. The questions Who am I? and Where do I belong to? arise quite often in our minds. In the past, an individual was bound by its social status, gender identity and social traditions. In today's modern society, according to some even post-modern society, humans have gained enormous freedom. They can freely build their own identity, they can choose their own way of life, their partner, profession and all of that according to their own criteria. On the one hand, people have acquired enormous freedom. On the other hand, they were given responsibility for their lives. Seeking and creating one's own identity is a lifelong process and, in the context of macro-social changes in society, its complexity creates various kinds of problems and crises.
\end{abstract}

UDC Classification: 304, DOI: https://doi.org/10.12955/pss.v1.63

Keywords: identity, crisis, social change, traditions

\section{Introduction}

Changes in society sometimes take place very slowly, but occasionally, they can occur at a fast pace. Nevertheless, it is typical for us that we persistently strive to uphold and protect our traditions, even our ideas of raising children in the family. These traditional and outdated views are no longer beneficial in all cases because our values have already changed. While up to recently the trend has been to work more for society and for our social environment, today it is personal, individual success that is valued much more. Ironically, we keep reminding ourselves of our "centuries-long traditions" at various public occasions. This way of thinking can be observed in our folk traditions, starting from the beginning of a new year: we wish one another all sorts of achievements, but mainly good health, happiness and satisfaction, not even thinking about that we should accomplish this by ourselves. All good things are supposed to fall into our lap, just like a lottery win, and when that does not happen, someone else is always to blame. This traditional mindset brings about certain 'schizophrenia' in society. Theoretically and verbally we declare our "loyalty" to traditions. But in practice, we identify ourselves with the newer thinking, the new values, such as "carpe diem", preferred individual success and so forth.

\section{Identity creation}

The development of our identity is a continuous process starting from the moment we begin to distinguish ourselves from others, e. g. I'm a man. ... I'm a woman. ... I'm a European. ... and I do not like curds. In this process, our identity is being associated with society and its culture. We still insist that for socialization to be as best as possible, it is essential to have a solid family background, because relationships within the family, its habits and moral beliefs most strongly formulate the needs and values of a human. In completing this process, we are assisted by a variety of systems whose task is to organize the function of society. This includes written rules (laws), the violation of which is punished by sanctions from the state, but also their unwritten counterparts (customs). We consider these rules to be the norms of society, which include concepts such as values and ethical aspects.

The creation of identity or individualization is a continuous development of personality, always during a certain period of life. Identity comes from Latin identicus "identical". Generally speaking, it is the unity of inner psychic life and action, also called authentic being, which is a term used in various meanings. E. H. Erikson (1950) uses it to denote the essential feature of adolescence, associated with the questions Who am I? Am I an adult? A. H. Maslow (1994) characterizes it in his humanistic psychology as the ability to be "what I really am", i.e. to be oneself. It is an effort to achieve selfrealization.

In social psychology, identity is broadly understood as the authentic being. Its opposite is the inauthentic being, i.e. pretense. In philosophical anthropology, we understand it as "life in truth". In sociology, identity is tackled by R.G. Dahrendorf (1950) and E. Goffman (1959) (Petrusek, Vodáková, 1996., p. 414).

Awareness of one's self is a process, which begins at an early childhood. In its course, we learn to distinguish ourselves from others. The development of our personality, our selves, is a process that accompanies us since our birth, when we have no idea of society, throughout our lives. As Parsons

\footnotetext{
${ }^{1}$ Danubius University, Sládkovičovo, Slovakia, hermina.marekova@gmail.com
} 
puts it in 1956, "The birth of every new generation of infants is a recurrent barbarian invasion..., because the newborn does not have the slightest idea about the rules and norms of the society in which s/he was born." (Parsons, Bales, 1956).

It is difficult to describe how exactly the importance of some values has changed for the modern human in our industrialized world, but based on recent research, it seems that in the modern world, individual results, success, development and wealth are more important than in the pre-industrialized world.

Adolf Dyker gave his wife a small bag with a watch, diamond rings, a gold chain and 200 Swedish crowns. Stewart Collett, a young student of theology, took his Bible, Lawrence Beesley his books and waiter Johnson put four oranges in his uniform pocket. These images originate from the dramatic moment when Titanic was sinking and people were making decisions, what is the most valuable to be taken with them before their end (Lord, 1979).

Values refer to what is good and what is bad. Every person has his or her own value system and organizes the hierarchy of values according to the level of his/her culture. In the theories of cultural anthropology, people in traditional society do not have the possibility to make decisions. They follow values in accordance with the adopted culture, and that is the result of social individualization (Hanák, 1973). Traditional societies have devalued their collective value system through modernization. Rather than opting for collective values, they can individually choose from a wide range of facultative values in order to create their identity.

Values and culture are closely interconnected. Values can be studied in various ways. The best known of them is the Hofstede experiment (1980). In the years 1967 to 1973, 117,000 people living in 50 countries of the world were asked questions. Their responses were processed by factor analysis and, based on the results, Hofstede divided the value charts into four dimensions. The first dimension comprises power versus independence from power. The second dimension is search for uncertainty vs. circumvention of uncertainty. The third dimension is individualism vs. collectivism. The fourth dimension is masculinity vs. femininity. A similar trend was described also by Inglehart (Inglehart, Abramson, 1977, 1995). The results of repeated research put value issues at the forefront of identity formation.

In the last half-century, the principles of behavior in Western societies have changed fundamentally. Traditional patterns, values of behavior have been replaced by new, often quite opposite norms. The traditional and also the modern systems of values are thus replaced by a new value system, the "postmodern" one. Instead of the traditional/modern value of "love your neighbor", the currently expected norm is "love yourself". Instead of "sacrifice for society", self-realization is appreciated (over the dead bodies, so to speak). Previously, it was the norm that everyone worked. Today it is of greater value when we have a good time. In the past, compliance with obligations was almost a mandatory standard. Today, everyone is supposed to protect her/his rights. We all know and use in everyday's life the term "I have the right to...", "I can make decisions as I want". They are used without respect to others, as if we could exist in a society without other people. It even seems to us that most of society behaves according to this principle.

According to Andorka (2003), the results of research are ambiguous, but most of it agrees that it is a disadvantage for children and especially boys to grow up in a fatherless family and socialize instead through public mass media channels. A whole new research direction has emerged, which examines the question of the impact of television programs on the socialization of children and whether it is positive or negative. It is believed that watching TV for more than ten hours per week has a negative impact on children. Another, no less frequent research question is: what is the impact of strict vs. benevolent upbringing in school and family on personality development, on child identity creation. Today our schools provide children with every help imaginable in dealing with the tiniest problems. Of course, without any effort on the side of the children. It is enough to simply report the problem and the solution (responsibility for the outcome) is transferred from the child and especially from the parent onto the institution. Everyone is suddenly happy - the parents, the school and the child. However, it is difficult to predict how such "eased" socialization educates a person who will then expect the arrival of an assistant to solve the difficulties instead of him/herself. Ellis (2008) considers the generation born 1980 to 2000 to be hopeless, as this generation loses an emotional connection with 
the real world in favour of internet addiction. He blames the parents of the "baby boom" generation who raised their children too protectively, as a result of which this generation is not ready for reality. The individuals respond to such illusory education with sentimentality. This generation resents criticism; anyone who dares to criticize on online forums, will receive a derogatory reaction or even bullying in the real world. Due to the difficult economic situation, young people with a university degree are often unable to find a job. No wonder they prefer living on social networks rather than in reality. According to Ellis (2008), today's young people do not want to create anything. Alternatively, they try to "steal" art or identify with it.

\section{Identity Formation}

According to Pataki, identity is one of the most important psychological mediating constructs between a human and society (Pataki, 1982a, p. 248). Csepeli says (2002) that since the moment the term was introduced by Erikson, there has been much controversy around it in social psychology as well as in psychology and sociology, and it can be said that the term has become very "fashionable" not only in scientific circles, but also in women's magazines. It is also used by fraudsters, among others. Science and life have met, says Csepeli (2002).

Etymologically, the word identity/identical can be derived from Latin idem "the same" and bears the meaning "the quality or fact of being the same, sameness in all characteristics; selfhood". In psychology and philosophy, it is a concrete, integral, unmistakable essence that differs from one human individual to another (Buchtelová et al., 2008, p. 410).

Essential for a person's identity is what they consider to be their own value and whether they can identify with that value. "The most basic question", writes Malík (2012, p. 111), "which we must ask ourselves when talking about today's identity crisis, is the question that appears to disqualify every attempt to raise the topic in the first place, namely whether there is still something to ask about. Whose identity are we talking about? Who is actually affected by the crisis? Can the crisis affect someone who has not been here for a longer time? Of course, the human is still here, with the only difference that he is no longer anything, that he no longer means anything, that he has become insignificant. The crisis-forming potential of this day and age is also enhanced by the fact that humans want to regain their lost significance in this world with the help of their medialization, technology or money."

The question of identity was also addressed by Taylor. He describes the circumstances of its origin or its outbreak as follows: "The notion of identity refers to certain evaluations, which are essential because they are the indispensable horizon or foundation, out of which we reflect and evaluate as persons. To lose this horizon, or not to have found it, is indeed a terrifying experience of disaggregation and loss. This is why we can speak of an 'identity crisis' when we have lost our grip on who we are." (Taylor, 1983, p. 35).

According to Malík, "the course and result of the identification can vary. An individual can aquire a picture of her/himself as a separate being through individualization" (2011, p. 70), or, according to Parker (2008, p. 45), "our identity comprises all parts of our lives and it is an ever-evolving seed where our genetics, biology, culture, our relatives whom we have cared for, whom we have hurt, our good and bad deeds that we have done for or against ourselves, our experiences and decisions together mean who I am at the moment". Person's identity is determined by what they consider important, the values with which they identify themself, but especially what they consider to be good.

\section{Identity crisis}

The privileged life, according to Ellis (2008), becomes empty sooner or later and eventually aggression, perversity and showiness appear. When expensive suits or handbags from Gucci lose their value, aimlessness sets in. An identity crisis.

"The identity crisis we are talking about is mainly related to the erosion of traditional identities and the paralysis of the mechanisms of their formation. So far, humans have created their identities in two ways: in a positive way - identification, subscribing to a certain, already established and thus firmly anchored and clearly contoured identity, or by a negative definition - as the opposite of non-me. Of course, one of the prerequisites for shaping one's own identity is also the act of its recognition, which is, in its turn, a prerequisite for this individuality to become assured of itself. Said act is an act of verification of its own existence by its recognition (confirmation, 'taking note of') by others. This 
means that the ultimate condition for constituting an identity of a certain self was an act of recognition that is intrinsically linked to the presence of other people, i.e. it is intrinsically linked to the phenomenon of intersubjectivity." (Malík, 2012, p. 111).

A human then strives to confirm its existence by objectifying it in the world of things, by its "exteriorization", "visibility". "To be means to be seen", or, to put it better, "to be factualized", "to be on offer". This is very relevant nowadays (Rajský, 2009, p. 163).

"Culture is pulling the shorter end even where the market-driven (un)culture of instability and forgetfulness comes to play, which is a prerequisite of unlimited consumption." (Malík, 2012, p. 117).

The crisis in question has also been contributed to by processes that "softened the sharp edges of the world." "Anything goes" today (author's note: for more see Feyerabend, 1975).

"Avoiding the hard edges of life has always been a privilege of childhood, hence a sign of immaturity. However, children and young people were only protected from these collisions until a certain age. Eventually, one day a young person grew up and lost their privilege. Humans thus 'get on their feet" twice. For the first time they do it literally, when they learn to walk. The second time they do it symbolically, when they become independent of parental care and embark on their own career. Maturity always used to be proven by a test" (Malík, 2011, p. 70). We are currently seeing that the period of "getting on one's feet" is increasingly shifting, often until the third decade of the young. Society responds to this fact with tolerance. There is even a different view on a thirty-year-old man living with his mother as opposed to a thirty-year-old woman living with her parents. While the first case is considered a result of young people's comfort and 'calculations', because they are provided with food, laundry, they do not pay for energy, so they can spend a considerable amount of their income (often higher than their parents') on their hobbies. In the case of a woman, the gender stereotype "prescribes" participation in housework exclusively to the woman, and in this case it is assumed that the daughter residing with her parents is automatically involved in the maintenance of the household and the care for family members.

According to some authors, it is parents who did not prepare their children (born 1980 to 2000) for reality and are responsible for this situation. Their upbringing was too protective. "You no longer hit hard edges - the world no longer resists us, but on the contrary - the world gives way and adapts itself to our slightest whims. We do not have to make any effort and intervene in the world, because the world comes to us, it is at hand, put at our feet. Everything under the sun is ours and is available to us. "'(Malík, 2011, p. 70).

Instead of seeing reality, an individual reacts uncritically to failure and responds with sentimentalism to any criticism, presenting him/herself as a victim. The generation theory by two Americans, William Strauss and Neil Howe, especially in their book entitled Generations (1991), was very influential. They say that members of a given generation have a very similar worldview and value ranking. In fact, human life lasts about 80 years, which they call saeculum, and during this period, four exchanges of generations take place, approximately every 20 years. These exchanges follow each other cyclically, in exactly the same way.

Why is it good to know this? Applied generational theory can greatly help us in generational coexistence ("maybe they are not worse, but they are certainly different"). It is not yet possible to say to what extent is this change radical, but the very fact that people born after 2000 who are digital natives compared to parents who are digital immigrants, can strongly affect the process of socialization and identity creation, both positively and negatively.

As Bauerlein (2011) points out, young people have too many choices, too much freedom of choice, so that their teachers do not have a major influence upon them. There are too many offers and when choosing, young people often do not have a solid background in the form of a family and therefore have no possibility of correcting their opinions through interactions (Grotevant, 1997).

We are witnessing a rapid scientific and social progress, during wich it is very difficult to maintain our own identity, and therefore the identity crisis is causing us to fear our own freedom. Our call for an order is a call for a lost identity, perhaps the false one. It is not possible to create an identity by depriving someone else of theirs. After a certain stage of life, everyone finds out what is most accepted in society, and if it is the life of rich "yuppies", then they will certainly try to live by it because they want to belong to this privileged group, in order to not miss anything "valuable" in life. 


\section{Conclusion}

According to Csepeli (2002), today's world is becoming more and more manipulative and, at the same time, is making us defenseless and helpless. Which is, of course, a negative phenomenon. On the positive side, there is the possibility of rapid and mass self-correction and adaptation. Today's fourtyyear-olds have become technological exhibitionists. They have created personalities, with which the elderly have nothing in common. The next generation is even worse: It has definitely lost its emotional connection with the world (Ellis, 2017). This generation solves everything through electronic media and "googling" is taking enormous proportions. It seems as if there was an ancient stereotype in society - a tendency to believe things if they are written "black on white" or "what is written is given". At a certain point, the role of written documents was partly taken over by television. What once appeared on TV screens was considered true. Public consciousness is often manipulated deliberately, and it is very difficult or even impossible to change the mass beliefs of society, even after a disclosure of deceptive information.

Many of us cannot even imagine our lives without social networks. Google has become a window into the world, but like every tool, it is not devoid of danger. The answers we receive are, to a greater extent, dependent of what we were looking for in previous search sessions. This means that many people are increasingly enclosing themselves in their customary thought processes. Instead, they need new ideas that other people might come up with. This fact has been noticed by scientists and it has given rise to an initiative called Data Portraits by E. Graells et al. (2013): Connecting People of Opposing Views. The team introduced a program that can help us escape the so-called filter bubble. Social networks currently do not support creativity, development, but rather the same views, as a result of which we move along our beaten paths of thought. This fact can greatly affect the formation of an individual's identity and we do not yet know to what extent it will affect our lives.

\section{References}

Andorka, R. (2003). Bevezetés a szociológiába [Introduction to Sociology]. Budapest, Hungary: Oziris.

Balla, E. (2014, October 10). Bret Easton Ellis: Itt a balfasz nemzedék [Bret Easton Ellis: Generation Wuss]. Retrieved from: http://valasz.hu/vilag/bret-easton-ellis-itt-a-balfasz-nemzedek-105285

Bauerlein, M. (2011). Najhlúpejšia generácia. Ako digitálna éra ohlupuje mladých Američanov a ohrozuje našu budúcnost' [The Dumbest Generation: How the Digital Age Stupefies Young Americans and Jeopardizes Our Future]. Bratislava, Slovakia: Vydavatel'stvo Spolku slovenských spisovatel'ov.

Buchtelová, R. and col. (2008). Slovník cudzich slov [A Dictionary of Foreign Words]. 3rd edition. Bratislava, Slovakia: Slovenské pedagogické nakladatel'stvo - Mladé letá.

Csepeli, G. (2002). Szociálpszichológia [Social Psychology]. Budapest, Hungary: Oziris.

Dahrendorf, R. G. (1950). In: Petrusek, M., Vodáková, A and.col., 1996. Velký sociologický slovník [Large Sociological Dictionary] I., II., Prague, Czech Republic: Karolinum.

Erikson, E. H. (1950). Childhood and Society. New York, USA: Norton.

Feyerabend. K. P. (1975). Against Method: Outline of an Anarchistic Theory of Knowledge. London, UK: New Left Books. Goffman, E. (1959). In: Petrusek, M., Vodáková, A. 1996. Vel'ký sociologický slovník [Large Sociological Dictionary] I., II., Prague, Czech Republic: Karolinum.

Goffman, E. (1961). Asylums: On the Social Situations of Mental Patients and Other Inmates. New York, USA: Garden City, Doubleday and Company.

Graells, Garrido, E.G., Lalmas, M., Quercia, D. 2013. Data Portraits: Connecting People of Opposing View. Retrieved from: https://arxiv.org/abs/1311.4658

Grotevant, H. D. (1997). Family Processes, Identity Development, and Behavioral Outcomes for Adopted Adolescents. Journal of Adolescent reseach, 12. I. 139.

Hanák, P. (1973). Népi levelek az elso világháborúból [Civilian Letters From the First World War]. Budapest, Hungary: Valóság 16, 3, 62-87.

Hofstede, G. (1980).Culture's Consequences: International Differences in Work related Values. Beverly Hills, CA, USA: Sage.

Howe, S., Strauss, W. (2000). Millennials Rising: The Next Great Generation. New York, USA: Vintage Books. Toronto, Canada: Random House of Canada Ltd.

Inglehart, R., Abramson, P. R. (1995). Value Change in Global Perspective. In: Andorka, R.: 2003. Bevezetés a szociológiába [Introduction to Sociology]. Budapest, Hungary: Oziris. p. 656.

Lord, W.(1979). A Titanic pusztulása [A Night to Remember]. Budapest, Hungary: Kossuth kiadó. 
Malík, B. (2014). Rodové diferencie a ich vzt’ah fenoménu literárnosti - slovo na obranu mužov [Gender Differences and Their Relation to the Phenomenon of Literariness - A Voice to the Defense of Men]. In: Antonín Kozoň a kol. Sociálne zdravie jedinca a spoločnosti [Social Health of the Individual and Society]. p. 94.

Malík, B. (2012). Politická antropológia - Futurológia bez budúcnosti [Political Anthropology - Futurology Without a Future]. Bratislava, Slovakia: Iris.

Malík, B. (2011). Súčasná identitárna kríza: jej príčiny a dôsledky pre školu [The Current Identity Crisis: Its Causes and Consequences for Schools]. In: Kudláčová, B.(ed.). Topológia človeka v relácií k výchove a vzdelávaniu v obdobi postmoderny po súčastnost' [Human Topology in Relation to Upbringing and Education in the Postmodern Period to the Present]. Trnava, Slovakia: University of Trnava, 2011. 61-73.

Marcia, J. (1980). Identity In Adolescence. In: Adelson, J. Handbook of adolescent psychology. I. ed. New York, USA: Willey.

Maslow, A. (1994). A theory of human motivation. Psychological Review, 50(4), 370-396.

Parker, N. (2008).The Geopolitics of Europe's Identity. New York, USA: Palgrave Macmillan.

Parsons, T., Bales, R. F. (1956). Family socialization and Interaction Process. London, UK: Routledge and Kegan Paul London. Glencou Fee Press 1955.

Parsons, T. (1971). The system of modern societies. Englewood Cliffs. New Jersey, USA: Prentice-Hall.

Pataki, F. (1982). Az én és a társadalmi azonosságtudat [The Self and the Comprehension of Social Identity]. Budapest, Hungary: Kossuth kiadó.

Petrusek, M., Vodáková, A. (1996). Velký sociologický slovník [Large Sociological Dictionary] I., II., Prague, Czech Republic: Karolinum.

Rajský, A. (2009). Nihilistický kontext kultivácie mladého človeka [The Nihilistic Context of Shaping of a Young Man]. Trnava, Slovakia: Typi Unversitatis Tyrnaviensis.

Strauss, W., Howe, N. (2000). Millennials Rising: The Next Great Generation. New York, USA: Vintage Books. Toronto, Canada: Random House of Canada Ltd.

Taylor, C. (1983). Philosphical Papers 1. Human Agency and Language. Cambridge, Ma, USA: Harvard University Press. 